\title{
THE INFLUENCE OF TEMPERATURE ON MEIOSIS
}

\author{
G. J. DOWRICK \\ John Innes Horticultural Institution, Bayfordbury, Hertford, Herts
}

Received 27.ii.56

\section{INTRODUCTION}

THE main purpose of this investigation has been to study the influence of temperature on meiosis but the results have also been used to gain further knowledge of chromosome structure and behaviour. Many previous experiments have shown that changes in temperature can affect the general pattern of meiosis as well as the form and behaviour of the chromosomes (Plough, 1917, 1921; White, 1934; Barber, 1941, 1942 ; Swanson, 1941, 1942a and b, 1943, and Elliott, 1955). These earlier workers frequently considered only the influence of isolated temperatures or a comparatively small range of temperatures.

Chromosomes may exhibit three major effects from changes in temperature. These are alterations in the frequency and changes in the position of chiasmata and variations in internal coiling. All three effects may occur simultaneously but for convenience chromosome coiling will be considered separately. Other minor effects will also be considered.

\section{MATERIALS AND METHODS}

Clone $20^{1}$ of Tradescantia bracteata and plants of Uvularia perfoliata have been used in these experiments.

$\mathcal{T}$. bracteata $(2 n=12)$ has six bivalents indistinguishable at meiosis. Tests with it were carried out from August to October. Plants of $\mathcal{T}$. bracteata were grown for at least seven days in controlled temperature at $15^{\circ} \mathrm{C}$. Some were then placed in cabinets each maintained at one of seven temperatures between $15.5^{\circ} \mathrm{C}$. and $4 \mathrm{I} \cdot 0^{\circ} \mathrm{C}$. - the latter being the thermal death point of this plant. The cabinets were illuminated for $\mathrm{I} 6$ hours per day and the temperature controlled to within $\pm_{\mathrm{I}} \mathrm{I}^{\circ} \mathrm{C}$. of the experimental treatment. Chiasma frequencies were determined in plants which had been given different lengths of treatment. Pollen mother cell squashes were made using acetic-orcein as stain fixative.

In $U$. perfoliata $(2 n=14)$, meiosis takes place during March before the shoot appears above the ground. Control plants were grown at $6^{\circ} \mathrm{C}$. Experimental plants were grown in incubators at various temperatures between $17^{\circ} \mathrm{C}$. and $38^{\circ} \mathrm{C}$. The thermal death point of this plant lies between $38^{\circ}-4 \mathrm{I}^{\circ} \mathrm{C}$.

The seven bivalents of $U$. perfoliata are of three types as follows :-

Type A : I bivalent of long chromosomes with median centromeres. Chromosome length at metaphase of mitosis- $18 \mu$.

Type $B: 3$ bivalents of long chromosomes with subterminal centromeres. Mean arm length $-8 \cdot 3$ and $3 \mu$. Mean chromosome length- $\mathrm{I} \cdot 3 \mu$.

Type $C: 3$ bivalents of short chromosomes. Mean chromosome length $-4 \cdot 2 \mu$.

The chiasmata of the long and short arms of the Type $B$ bivalents have been scored separately. 
MIIII

ifitoo

200000

$\because 8$

1.. 
Anthers were fixed in acetic alcohol and prepared as squashes after staining by the Feulgen reaction.

No recovery time was allowed between treatment and the time of scoring.

\section{CHIASMA FREQUENCY AND POSITION}

(a) Tradescantia bracteata

Under field conditions there is terminal localisation of the chiasmata, interstitials being usually less than 2 per cent. Between $15^{\circ} \mathrm{C}$. and

TABLE I

The effect of six temperatures on chiasma frequency and position in samples of IOO PMC of $\mathrm{T}$. bracteata (controls at $15^{\circ} \mathrm{C}$.)

\begin{tabular}{|c|c|c|c|c|c|c|c|}
\hline Temp. & $\begin{array}{l}\text { Time } \\
\text { in hr. }\end{array}$ & $\begin{array}{l}\text { Interstitial } \\
\text { chiasmata }\end{array}$ & $\begin{array}{c}\text { Total } \\
\text { chiasmata }\end{array}$ & Temp. & $\begin{array}{l}\text { Time } \\
\text { in hr. }\end{array}$ & $\begin{array}{l}\text { Interstitial } \\
\text { chiasmata }\end{array}$ & $\begin{array}{c}\text { Total } \\
\text { chiasmata }\end{array}$ \\
\hline $\begin{array}{l}\text { Control } \\
20 \cdot 0^{\circ} \mathrm{C} \text {. }\end{array}$ & $\begin{array}{c}\ldots \\
12 \\
24 \\
4^{8} \\
9^{6} \\
19^{2}\end{array}$ & $\begin{array}{r}17 \\
37 \\
52 \\
101 \\
129 \\
121\end{array}$ & $\begin{array}{l}743 \\
773 \\
836 \\
847 \\
842 \\
883\end{array}$ & $\begin{array}{l}\text { Control } \\
34^{\circ} 0^{\circ} \mathrm{C} .\end{array}$ & $\begin{array}{l}\ldots \\
12 \\
18 \\
24 \\
48 \\
96\end{array}$ & $\begin{array}{r}17 \\
73 \\
186 \\
217 \\
104 \\
3\end{array}$ & $\begin{array}{r}757 \\
832 \\
984 \\
1006 \\
860 \\
431\end{array}$ \\
\hline $\begin{array}{l}\text { Control } \\
27 \cdot 0^{\circ} \mathrm{C} .\end{array}$ & $\begin{array}{c}\ldots \\
12 \\
24 \\
4^{8} \\
144\end{array}$ & $\begin{array}{r}14 \\
56 \\
\text { I } 34 \\
143 \\
147\end{array}$ & $\begin{array}{l}707 \\
757 \\
845 \\
849 \\
851\end{array}$ & $\begin{array}{l}\text { Control } \\
39^{\circ} 0^{\circ} \mathrm{C} .\end{array}$ & $\begin{array}{l}\ldots \\
12 \\
18 \\
24 \\
27 \\
30 \\
48\end{array}$ & $\begin{array}{r}\mathrm{I} 7 \\
8 \mathrm{I} \\
\mathrm{I} 4 \mathrm{I} \\
475 \\
283 \\
\mathrm{I} 5^{2} \\
0\end{array}$ & $\begin{array}{r}743 \\
810 \\
841 \\
1152 \\
961 \\
787 \\
72\end{array}$ \\
\hline $\begin{array}{l}\text { Control } \\
30^{\circ} 0^{\circ} \mathrm{C} \text {. }\end{array}$ & $\begin{array}{c}\ldots \\
12 \\
24 \\
4^{8} \\
19^{2}\end{array}$ & $\begin{array}{r}\text { I } 4 \\
61 \\
\text { I } 57 \\
\text { I } 57 \\
\text { I } 62\end{array}$ & $\begin{array}{l}707 \\
762 \\
871 \\
868 \\
870\end{array}$ & $\begin{array}{l}\text { Control } \\
4^{1} \cdot 0^{\circ} \mathrm{C} \text {. }\end{array}$ & $\begin{array}{l}\ldots \\
12 \\
18 \\
24 \\
27 \\
48\end{array}$ & $\begin{array}{r}14 \\
110 \\
232 \\
339 \\
226 \\
0\end{array}$ & $\begin{array}{r}707 \\
805 \\
930 \\
1084 \\
868 \\
56\end{array}$ \\
\hline
\end{tabular}

$34^{\circ} \mathrm{C}$. raising the temperature increases the number of interstitial chiasmata. This occurs gradually during the first 24 hours of treatment after which the number remains constant. After a slight rise at the 12 hour treatment, the frequency of terminal chiasmata also remains constant (table I and fig. I). From the appearance of the bivalents at diakinesis and MI it seems likely that chiasmata can be formed closer to the centromere than is usual under field conditions.

Above $34^{\circ} \mathrm{C}$. there is a further rise in the frequency of interstitial chiasmata during the initial period but the frequency rapidly falls off as the time of treatment increases-from 2 I per cent. after 24 hours at $34^{\circ} \mathrm{C}$. to less than one per cent. after 96 hours at the same temperature. The frequency of terminals is also lowered above $34^{\circ} \mathrm{C}$. though more slowly than interstitial ones. As a result of loss of chiasmata of both types MI cells at temperatures above $34^{\circ} \mathrm{C}$. are almost completely asynaptic (fig. 2). Such cells die. The highest 


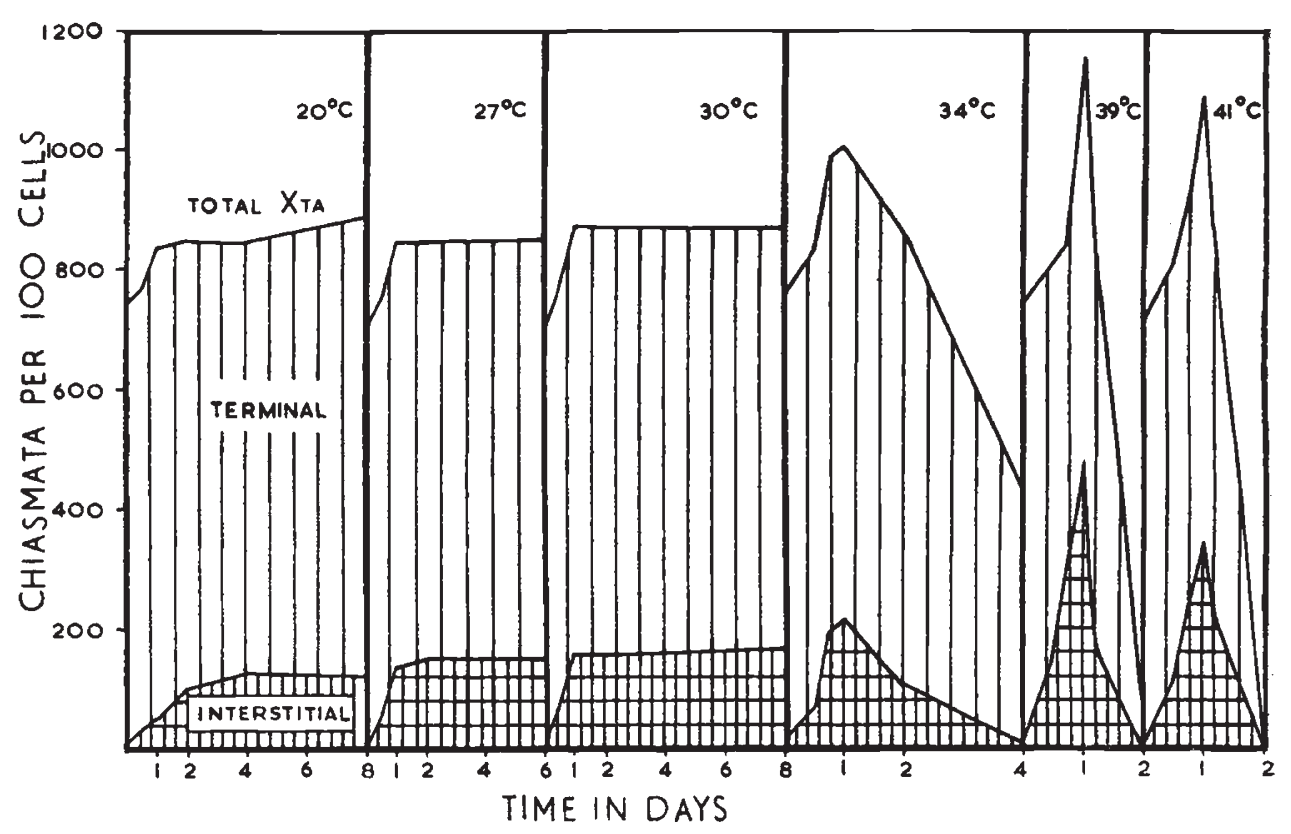

GRAPH 1.-The effect of temperature and time on chiasma frequency and position in $T$. bracteata.

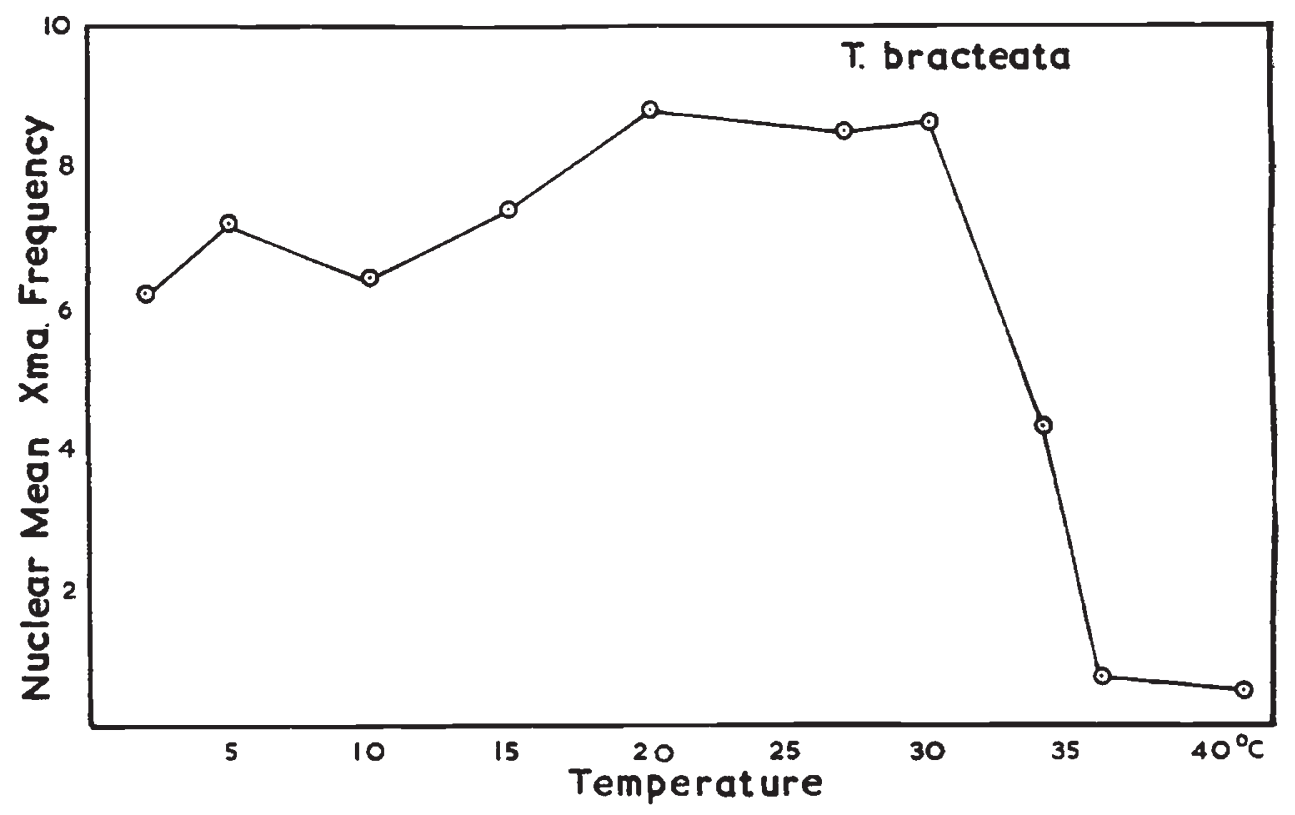

GRAPH 2.-The relationship between chiasma frequency and temperature in $T$, bracteata after long periods of treatment. 
total of chiasmata is seen after 24 hours at $39^{\circ} \mathrm{C}$. when it approaches. 1200 in 100 cells (graph I).

According to Snoad (unpub.) lowering the temperature below $15^{\circ} \mathrm{C}$. results first in a slight fall in chiasma frequency. A rise follows and then another fall affecting both terminal and interstitial chiasmata.

The influence of temperature after long periods of treatment is shown in graph 2 .

\section{(b) Uvularia perfoliata}

The various forms of bivalents have already been described. Under control conditions there are approximately 20 chiasmata per cell, six or seven being usually terminal. Chiasma frequency is indirectly proportional to chromosome length, long arms have more chiasmata than short but have a lower proportion of terminals (graph 3 , table 2).

As in $T$. bracteata chiasma frequency is correlated with temperature (graphs 3 and 4 ). Increases between $6^{\circ}$ and $21^{\circ} \mathrm{C}$. give more interstitial and, to a lesser extent, terminal chiasmata. Beyond $2 \mathrm{I}^{\circ} \mathrm{C}$. chiasma frequency falls owing to first, a reduction in interstitial chiasmata and also, at the highest temperatures, of terminals. The Type $A$ bivalents and the long arms of the Type $B$ bivalents in $U$. perfoliata have, however, a secondary region of chiasma formation (a secondary "contact point") close to the centromere. Consequently their terminalisation coefficient (T.G.) is at this stage lower than that of the other bivalents of the complement. After 24 hours' treatment at $38^{\circ} \mathrm{C}$. there is complete asynapsis (fig. 3 ). In $U$. perfoliata, unlike $T$. bracteata, duration of treatment makes no difference to the effect.

The effects of temperature are most clearly seen in those chromosomes with most interstitial chiasmata. Arms of similar length behave similarly. Thus the long and short arms of Type $B$ bivalents behave like Type $A$ and Type $C$ bivalents respectively.

As a result of the differential loss of chiasmata at the highest temperatures the chiasma frequency and distribution in the different bivalent types becomes similar as temperature is increased.

\section{CHROMOSOME COILING}

\section{(a) Tradescantia bracteata}

Below $34^{\circ} \mathrm{C}$. coiling follows a normal course while at higher temperatures abnormalities are found. After 6-12 hours' treatment above $34^{\circ} \mathrm{C}$. the ends of the free arms of some rod bivalents become despiralised-only a small part of a single major coil is involved, the remainder of the chromosome remains coiled normally (fig. 4).

After 12 hours more complete despiralisation of the major coils occurs. It begins at only three points. Most frequently it starts at a chiasma, less frequently at the centromere and only occasionally at the end of the free arm (table 3, fig. 4 and plate II, figs. 6-12).

Eventually the major coils disappear completely and the MI 


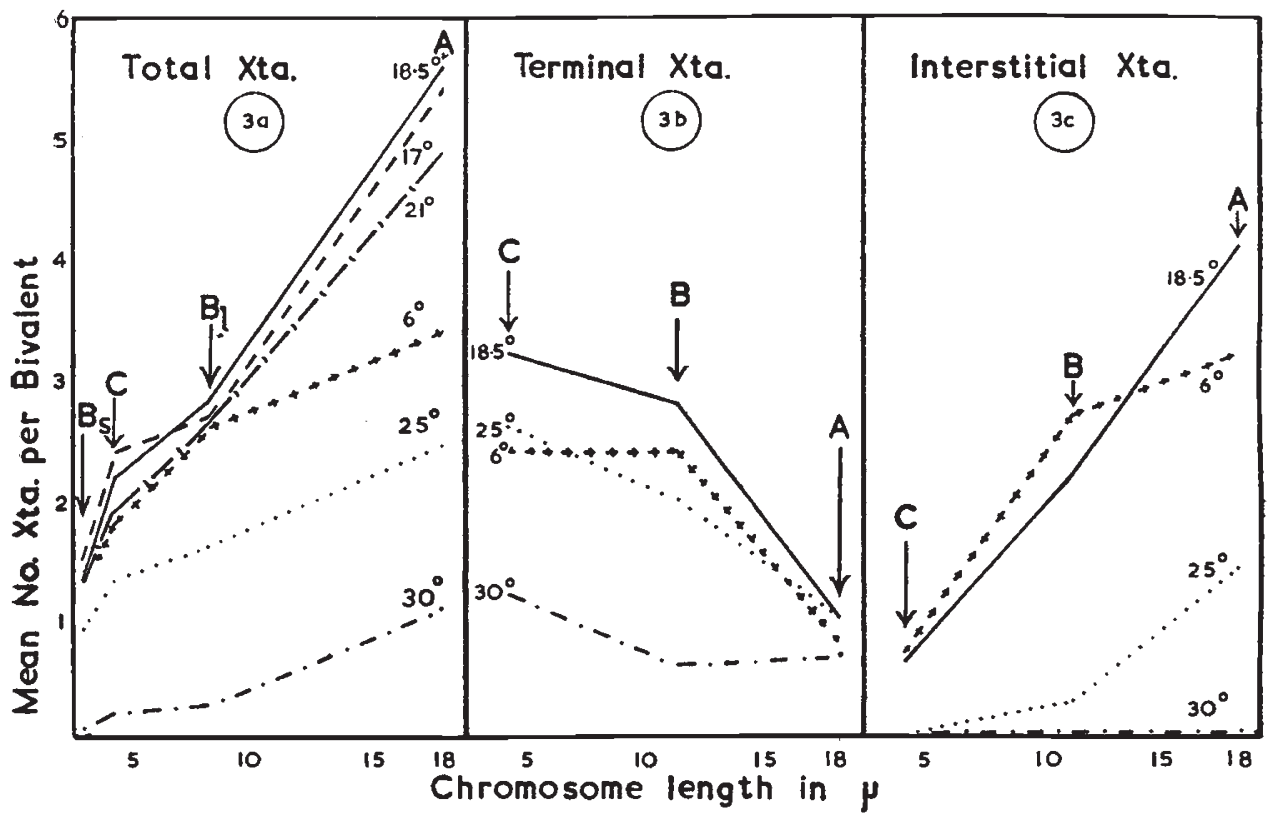

Graph 3.-U. perfoliata. Chiasma frequency and position in relation to chromosome length at 7 different temperatures. The frequencies at $17.0^{\circ} \mathrm{C} ., 18.5^{\circ} \mathrm{C}$. and $21 \cdot 0^{\circ} \mathrm{C}$. are very similar and in Graphs $3^{b}$ and $3^{c}$ the frequencies at $17^{\circ} \mathrm{C}$. and $21^{\circ} \mathrm{C}$. have therefore been omitted. The keys to Graphs $3^{b}$ and $3^{c}$ are the same as that of Graph $3 a$. In Graph $3^{a}$ the two arms of the Type $B$ bivalents have been plotted separately.

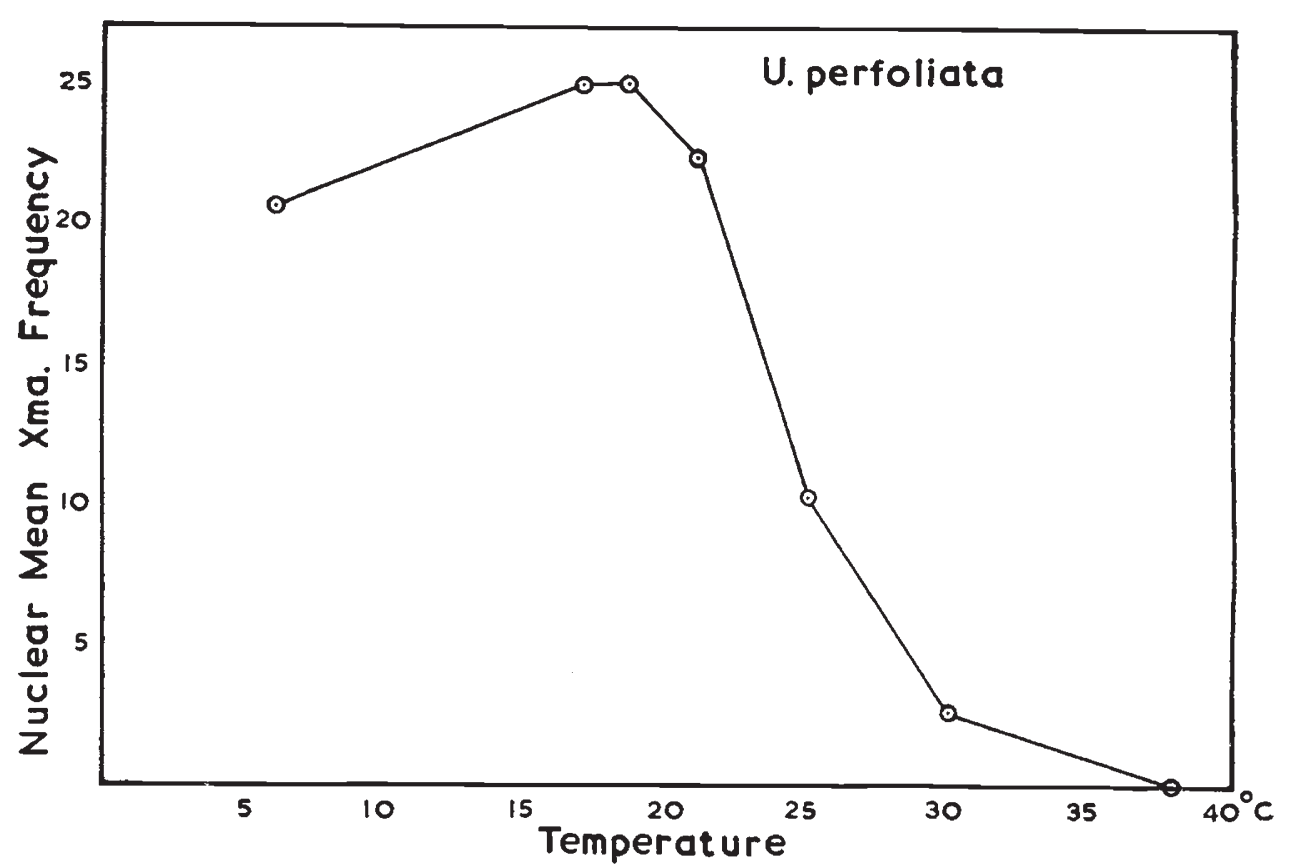

GRAPH 4.-The relationship between chiasma frequency and temperature in $U$. perfoliata. 


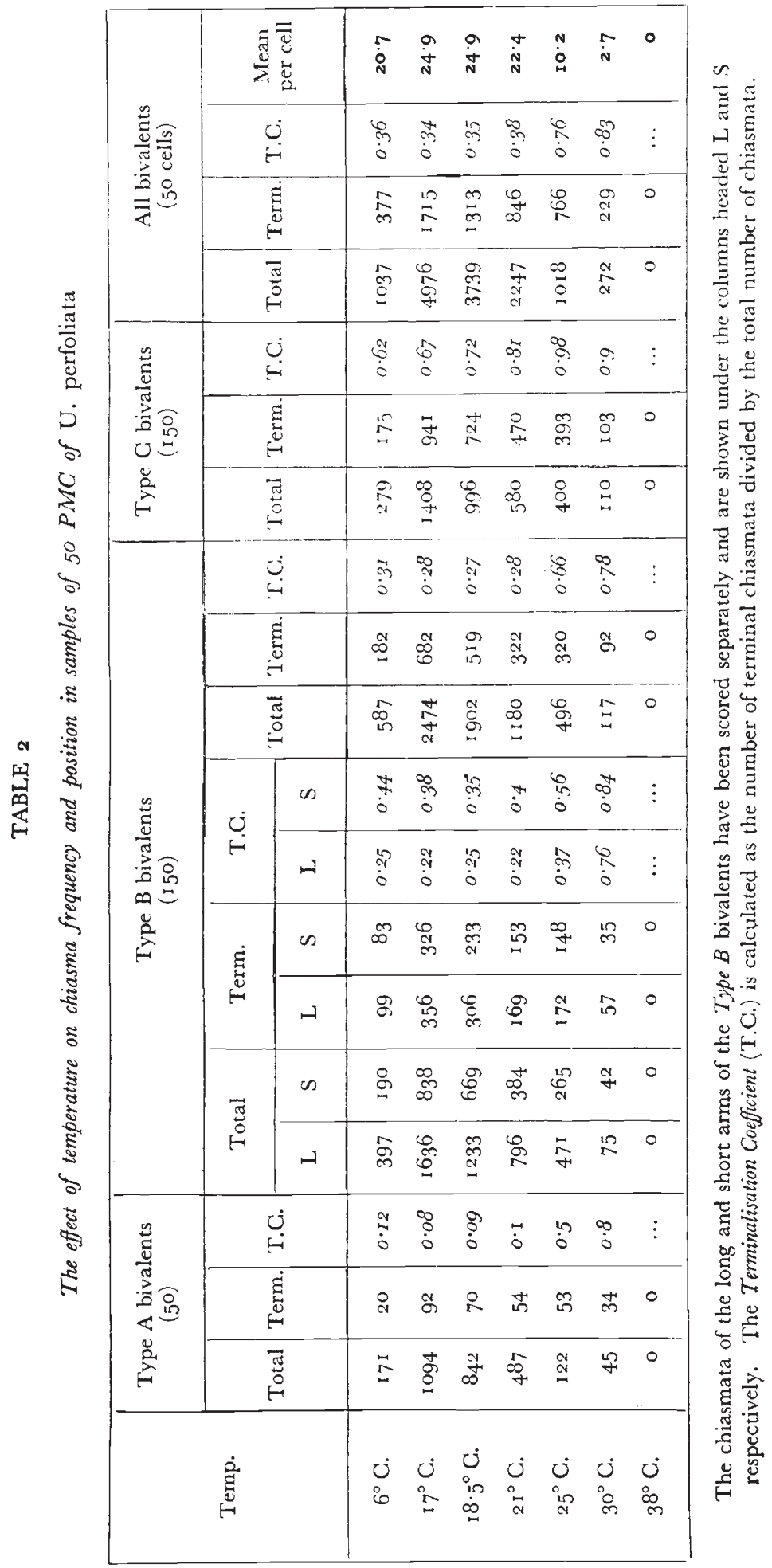


bivalents become long and thin (fig. 5, plate II, figs. 14 and 15). After 24 hours at $39^{\circ} \mathrm{C}$. all but one per cent. of bivalents are of this type. Their appearance is reminiscent of Triton chromosomes. Both

\section{TYPE A}

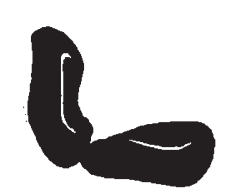

a
TYPE B

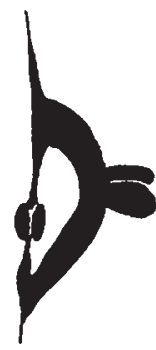

TYPE C

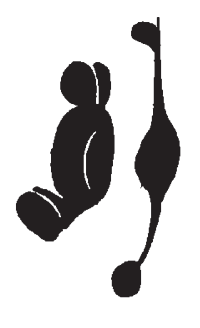

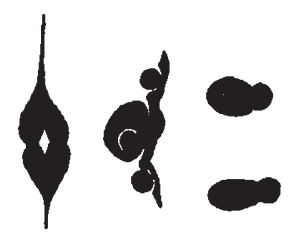

b
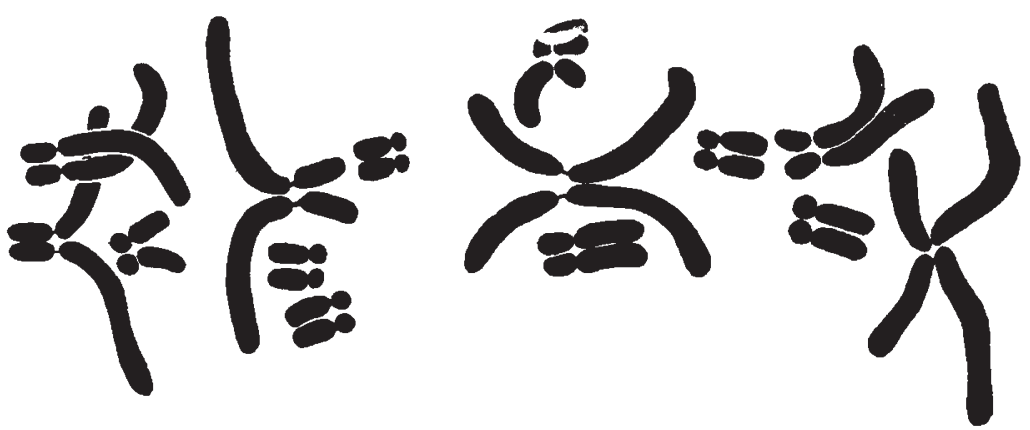

FIG. 3. $-U$. perfoliata. (a) MI after 6 days at $2 \mathrm{I}^{\circ} \mathrm{C}$., the three bivalent types have been separated; one $C$ type is unpaired : $(b)$ asynaptic MI devoid of major coils after 24 hours at $38^{\circ} \mathrm{C}$. $\times 2000$.

TABLE 3

The frequency of the different types of despiralisation

found in $\mathrm{T}$. bracteata after 18 hours at $4 I^{\circ} \mathrm{C}$.

\begin{tabular}{|c|c|c|c|}
\hline & \multicolumn{3}{|c|}{ Position of despiralisation } \\
\hline & At chiasma & At centromere & At end of free arm \\
\hline No. of bivalents & 183 & $3^{6}$ & 5 \\
\hline
\end{tabular}

chromosomes of one or two bivalents in 2 per cent. of these cells have additional, symmetrically arranged, constrictions. Most frequently they lie midway between the centromere and the end of the chromosome arm (fig. 5). Their constant size and position must result from the genetic property of the locus concerned, as in nucleic acid starvation (Darlington and La Cour, I940).

After long treatments over $34^{\circ} \mathrm{C}$. one per cent. of cells do, however, 

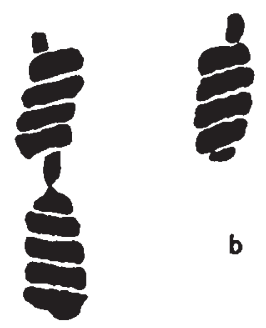

b

a

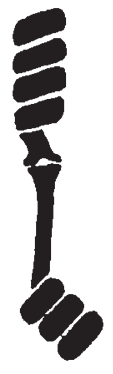

c

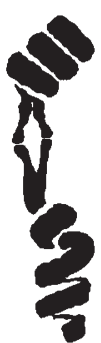

d

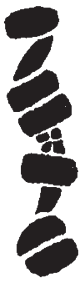

e

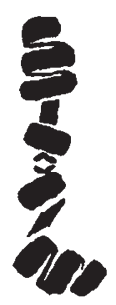

f

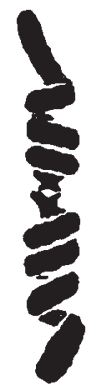

g

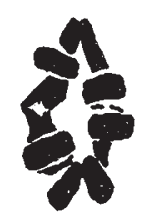

h

Fig. 4.-T. bracteata. (a) and (b) MI after 6 hours at $4 \mathrm{I}^{\circ} \mathrm{C}$. Uncoiling of a small part of a single major coil in (a) a bivalent and $(b)$ a univalent. $(c)-(h)$ bivalents from six different cells after 18 hours at $4^{\circ} \mathrm{C}$. showing the various types of despiralisation.

$(c)$ and $(d)$ Uncoiling commencing at the chiasma.

(c) and $(f)$ Uncoiling commencing at the centromerc.

(g) Uncoiling commencing at the ends of the free arms.

(h) Uncoiling commencing at the chiasma and at the centromere.

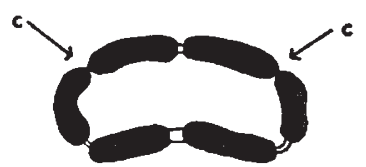

a
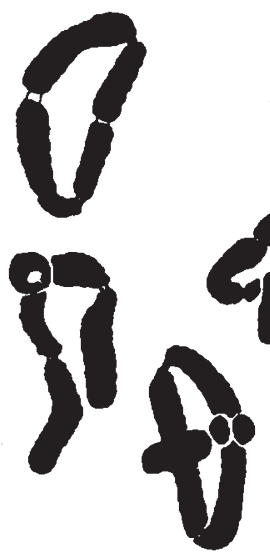

b

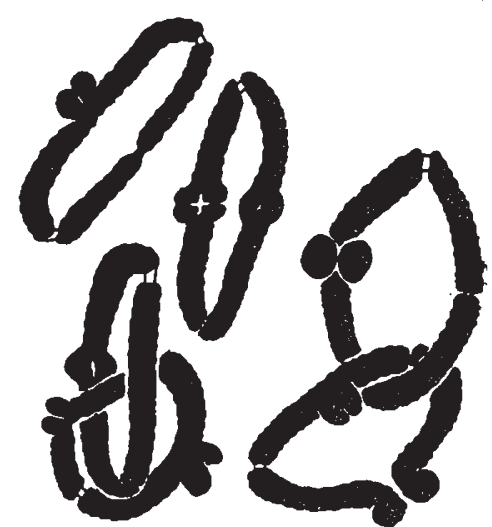

C

FIG. 5.-T. bracteata. (a) Single despiralised bivalent after 24 hours at $39^{\circ} \mathrm{C}$. showing the additional constrictions, $c$, seen only in heat-treated matcrial. (b) and $(c)$ two cells showing the increase in chromosome length between (b) diakinesis and (c) MI after 24 hours at $41^{\circ} \mathrm{C}$. Note the interlocking which occurs at high temperatures. $\times 2000$. 
show normal spiralisation but the chiasma frequency is reduced as mentioned previously (fig. 2).

One of the effects of heat treatment is to make the diffuse prophase of $T$. bracteata clearer and capable of analysis from diplotene onwards (plate II). After 24 hours' treatment at $39^{\circ} \mathrm{C}$. bivalents at diplotene sometimes show incipient major coils which are never seen, however, in MI bivalents after the same and longer periods of treatment. Major coils can therefore be formed or begin to be formed only to disappear before metaphase.

Between diplotene and MI the bivalents elongate considerably but during this period there is no visible alteration in the coiling system (fig. 4). The increase in length probably results therefore from the relaxation of some internal, perhaps molecular, coiling. It is not known whether these chromosomes contain more material at MI than at diakinesis, but it may be significant that ribose nucleic acid and possibly other substances are incorporated in chromosomes towards the end of prophase (Kaufmann et al., I949; Jacobson and Webb, I952 ; La Cour, 1954).

\section{(b) Uvularia perfoliata}

In $U$. perfoliata chromosome coiling at all temperatures below $25^{\circ} \mathrm{C}$. is similar to that of material grown under field conditions. After 24 hours at $25^{\circ} \mathrm{C}$. there is despiralisation of the major coils throughout the length of the chromosomes. Unlike $T$. bracteata this does not start at specific points but all parts of the chromosome are affected equally. After 24 hours at $30^{\circ} \mathrm{C}$. many bivalents are devoid of major coils while after the same period at $38^{\circ} \mathrm{C}$. there are no traces of major coils either at MI or during prophase.

\section{DISCUSSION}

The variations in chiasma frequencies brought about in $T$. bracteata and $U$. perfoliata by changes in temperature are similar to those found by Plough in Drosophila after consideration has been given to the mistake pointed out by Smith (1936). They are also similar to the results of Elliott with Hyacinthus orientalis and resemble those of White in species of Locusta, Schistocerca and Stenobothrus.

The reduction in chiasma frequency which occurs at high temperatures has not been demonstrated in animals nor in $H$. orientalis. While these temperatures would be lethal to the animals it seems likely that a reduction in chiasma frequency would have occurred in $H$. orientalis had the experiments been continued above $20^{\circ} \mathrm{C}$.

Experiments involving change in chiasma frequency and position are best carried out in plants with localised chiasmata. Under field conditions about 98 per cent. of the chiasmata are formed terminally in $T$. bracteata. That they are not formed interstitially and subsequently terminalised is clear from the very small size of the fragments which occur after crossing over has taken place within inversions. 
In $U$. perfoliata, on the other hand, the chiasmata are distributed along the length of the chromosome arms and up to eight may be found in the Type $A$ bivalents. There is little or no terminalisation.

In the absence of movement the number and position of chiasmata are directly related to the degree of chromosome pairing at pachytene (Darlington, I937). The differences in chiasma positions between $\mathcal{T}$. bracteat $a$ and $U$. perfoliata must then be related to differences in the pairing behaviour of their chromosomes. In $T$. bracteata pairing sufficiently intimate for chiasma formation is largely confined to the chromosome ends. Increase in temperature changes this localisation. Between $15^{\circ}$ and $34^{\circ} \mathrm{C}$. either pairing must be continued towards the centromere or another region near the centromere must become paired. This will increase the probability of the formation of interstitial chiasmata. Pairing at the chromosome ends must be unaffected since chiasma frequency at these points is unaltered.

At all temperatures between $6^{\circ}$ and $21^{\circ} \mathrm{C}$. pairing of the $U$. perfoliata chromosomes is presumably complete and other factors which influence chiasma formation must be sought. Among possible causes may be mentioned the interference distance between chiasmata. It is well known that the formation of a chiasma reduces the probability of the occurrence of another in an adjacent region. The present experiments suggest that increases in temperature between $6^{\circ}$ and $2 \mathrm{I}^{\circ} \mathrm{C}$. decrease the interference distances, possibly as a result of changes in the viscosity of the chromosomes.

The effect of high temperature is similar in the two species. There is a decrease in chiasma frequency from $34^{\circ}$ to $4 \mathrm{I}^{\circ} \mathrm{C}$. in $T$. bracteata and from $2 \mathrm{I}^{\circ}$ to $38^{\circ} \mathrm{C}$. in $U$. perfoliata. The decrease results from, first, a restriction of close pairing to the chromosome ends so that interstitial chiasmata are less frequently formed. Eventually there is an absence of pairing in both species and asynapsis results.

The maximum number of chiasmata are evidently formed at different temperatures in different species. This maximum is no doubt related to the conditions under which growth normally occurs. Most species will be adapted to give an optimum amount of crossing over at normal temperatures. The present experiments with Tradescantia and Uvularia suggest that this optimum is less than the maximum possible.

To explain the various changes in chiasma frequency, White suggested that changes in temperature bring about physical changes within the chromosomes and that the interference distance between chiasmata must be altered. The differential distance (Mather, I940) would presumably be similarly affected. While decrease in interference distances will account for the increase in chiasma frequency in $U$. perfoliata it cannot be considered in relation to $T$. bracteata.

All cell processes will be affected by changes in temperature and these may lead directly or indirectly to changes in the number and position of the chiasmata. As a result of increase in temperature the 
viscosity of the nuclear sap will probably be reduced. It appears that chromosome movement is speeded up more than the prophase as a whole. The increased chromosome movement might account for the high frequency of interlocked bivalents found in heat-treated material. At higher temperatures pairing, if it occurs at all, is confined to the chromosome ends and also in $U$. perfoliata to the centromere region of the long arms of Type $A$ and $B$ chromosomes. These are what Darlington (I940) calls the contact points in chromosome pairing.

The chromosomes undergo during the nuclear cycle a continuous and normally irreversible reduction in the number of coils. In these experiments, however, the reduction is reversed. As a result of spiralisation the chromosomes normally become progressively shorter. Swanson considers that low temperatures reduce the number of coils while high temperatures may completely inhibit their development. Observations in the present cases agree with these findings except that high temperatures do not necessarily completely inhibit the development of the major coils. They begin to form in $T$. bracteata and subsequently disappear.

The coiling spiralisation which occurs during normal prophase and which Swanson considered as uncoiling must not be confused with the abnormal despiralisation occurring at high temperatures. Coiling spiralisation, affecting all parts of the chromosome equally, decreases chromosome length, while the abnormal despiralisation, starting at specific points on the chromosome and extending along it, increases its length.

A comparison of meiotic chromosomes without major spirals with normal mitotic chromosomes is also of interest. As Darlington points out, the nucleolar constrictions are probably constrictions of the minor coils because they are not visible at MI. The small terminal nucleolar organisers of $T$. bracteata, visible at mitosis, are, however, not seen in the abnormal meiotic chromosomes which are devoid of major coils but have minor coils.

Similarly, in the abnormal meiotic chromosomes additional constrictions, constant in size and position, are seen. It is known that high as well as low temperatures lead to abnormality in heterochromatin (La Cour, I954). Tradescantia cannot be grown satisfactorily at temperatures low enough for the study of heterochromatin. The abnormal constrictions seen in these $T$. bracteata bivalents at high temperature may then be heterochromatic and invisible at metaphase except at these temperatures of $34^{\circ} \mathrm{C}$. or above. La Cour (unpub.) has recently found small segments of heterochromatin present in the resting nuclei of $T$. bracteata.

Any alteration in the number and position of the chiasmata would have evolutionary significance to the species concerned. A sudden rise in temperature in $\mathcal{T}$. bracteata and $U$. perfoliata would release new genetic variability. Alteration of other agencies which affect chromosome movement, e.g. the amount of infra-red radiation, would probably 


\section{Plate I}

The influence of temperature on chiasma frequency and position.

Tradescantia bracteata

Fig. I.-MI from control material. $\times 1600$.

Fig. 2.- MI after 18 hours at $34^{\circ} \mathrm{C}$. $\times 1600$.

Fig. 3.-Asynaptic MI after 24 hours at $39^{\circ} \mathrm{C} . \quad \times 1600$

\section{Uvularia perfoliata}

FiG. 4. - MI after 6 days at $21^{\circ}$ C.: $6^{11}+2^{1} . \quad \times 1000$.

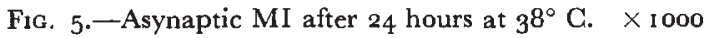




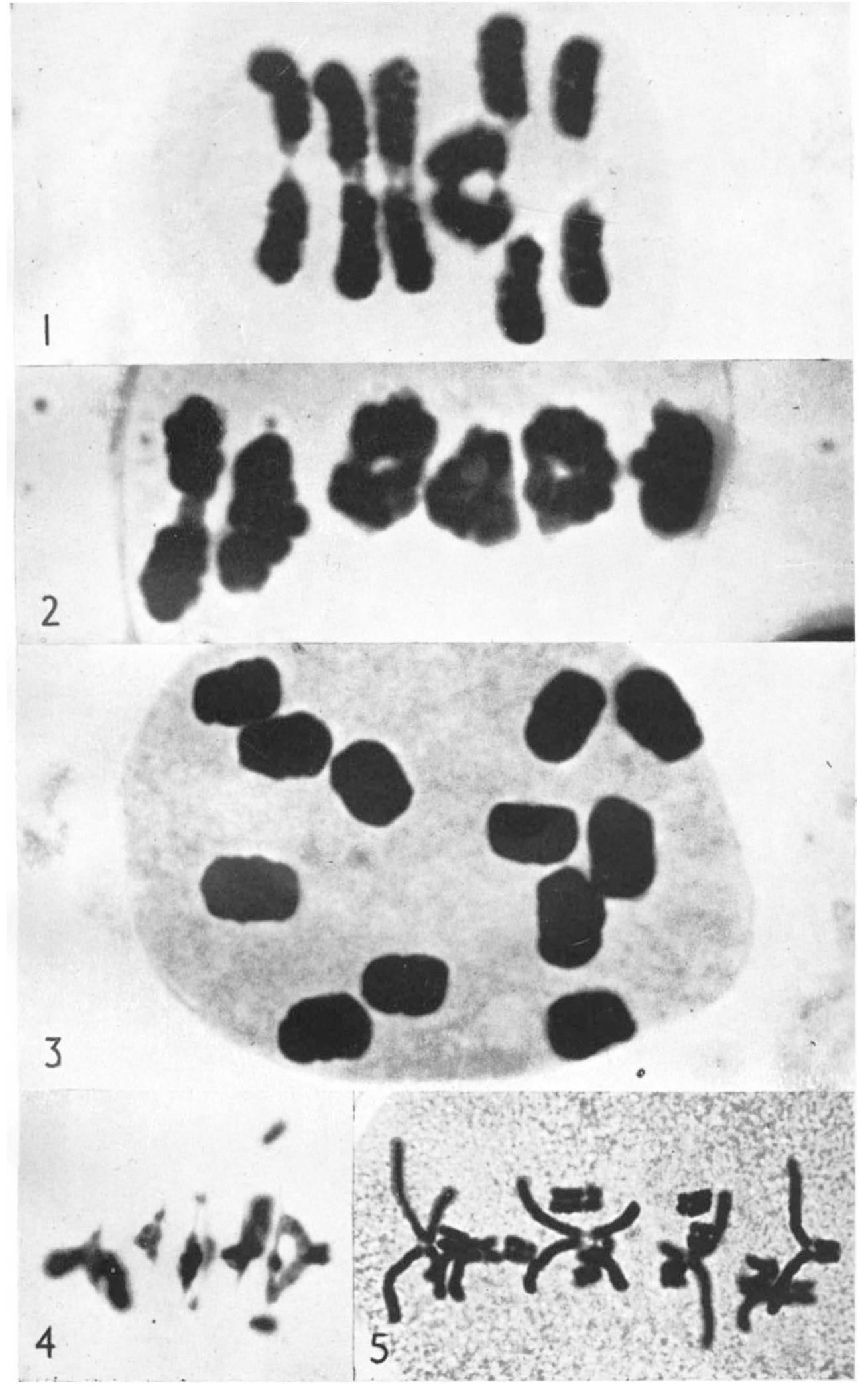




\section{Plate II}

Tradescantia bracteata

Figs. 6-10.-Individual bivalents at MI after 18 hours at $4 \mathrm{I}^{\circ} \mathrm{C}$. showing the various types of despiralisation. $\times 2$ I 00 .

FIGS. I I-I 2.- Individual bivalents at diakinesis after 24 hours at $39^{\circ} \mathrm{C}$. Major coils can still be seen. $\times 2100$.

FIG. I3.-Diplotene after 24 hours at $39^{\circ} \mathrm{C}$. with partially developed major coils. These disappear by MI. $\times 2100$.

Fig. I4.-Early MI after 24 hours at $4 \mathrm{I}^{\circ} \mathrm{C}$. (same as text fig. $5^{b}$ ). $\times 1600$.

Fig. I5.-MI after 24 hours at $4 \mathrm{I}^{\circ} \mathrm{C}$. The ring bivalent at the right with two interstitial chiasmata has been broken by squashing at a centromere. The ring bivalent at the left shows relational coiling. $\times 1600$. 


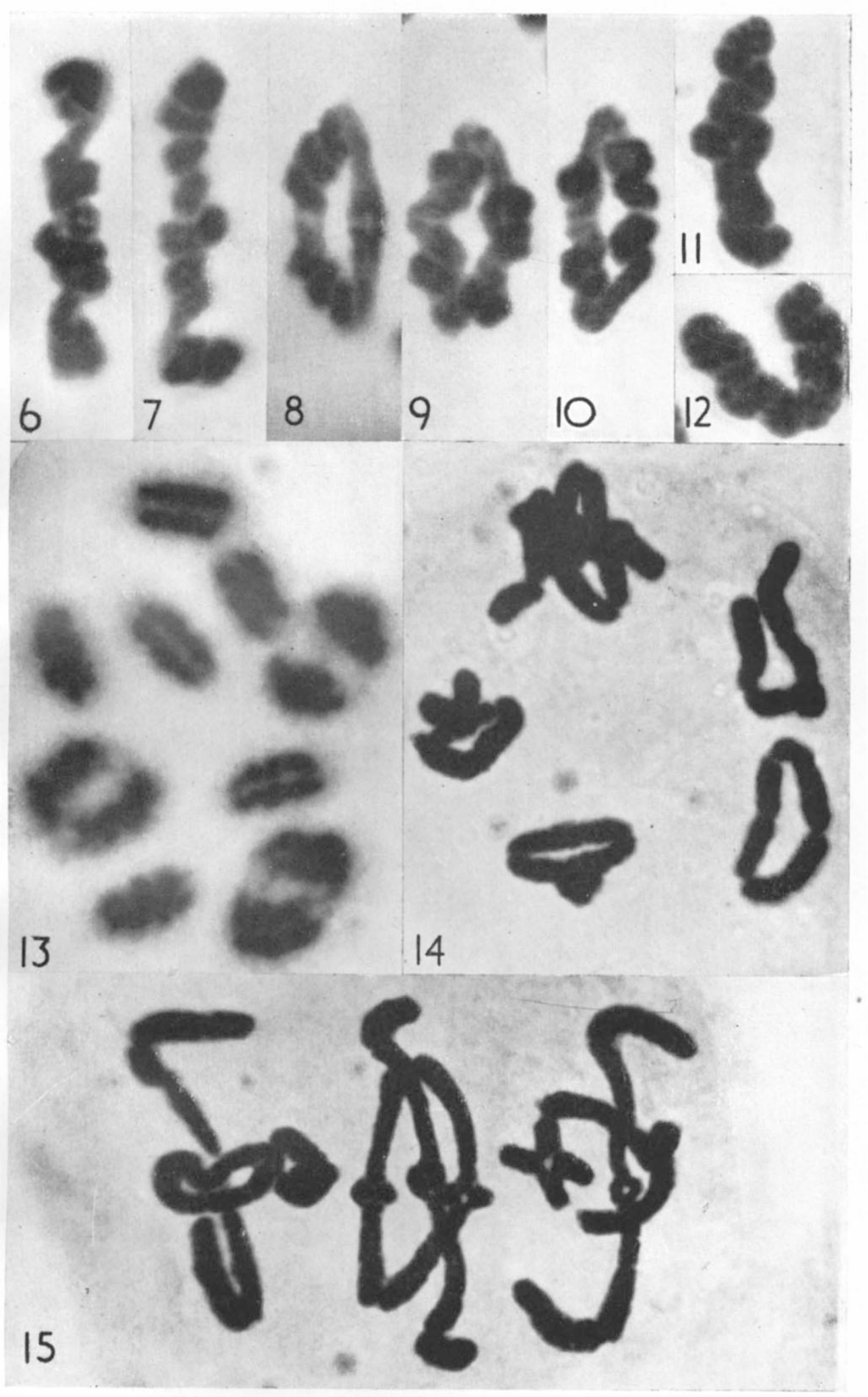


have similar effects and treatments of this type may have considerable practical application in plant breeding.

\section{SUMMARY}

I. In Tradescantia bracteata and Uvularia perfoliata high temperatures affect $(a)$ the number and position of the chiasmata, and $(b)$ the coiling of the chromosomes at meiosis.

2. Increase in temperature results in an increase in the frequency of interstitial chiasmata. This, as Darlington (I940) has suggested, could be related to an increase in the rate of zygotene pairing. The increase is followed at higher temperatures by a fall in both terminal and interstitial chiasmata : asynapsis results.

3. At high temperatures prophase is much clearer than is usual in T. bracteata. Spiralisation is also abnormal : major coils open out and finally disappear. In $\mathcal{T}$. bracteata as opposed to $U$. perfoliata the major coils begin to open out at specific points.

4. When major coils are absent constrictions, not normally visible, can be seen on some chromosomes of $\mathcal{T}$. bracteata. These are probably in heterochromatic segments.

\section{REFERENCES}

Barber, H. N. 1941. Chromosome behaviour in Uvilaria. 7. Genet., 42, 223-257.

BARBER, H. N. 1942. The experimental control of chromosome pairing in Fritillaria. J. Genet., 43, 359-374.

Darlington, c. D. 1937. Recent Advances in Cytology. 2nd Ed. London : Churchill. DARLington, C. D. 1940. The prime variables of meiosis. Biol. Rev., 15, 307-321. DARLington, C. D., AND LA COUR, L. F. 1940. Nucleic acid starvation of chromosomes in Trillium. 7. Genet., 40, 185-2 13.

ELliotT, c. G. 1955. The effect of temperature on chiasma frequency. Heredity, 9, 385-398.

JACOBSON, W., AND WEBB, M. 1952. The two types of nucleoproteins and mitosis. Exp. Cell Res., 3, 163-183.

KAUTMANN, B. P., MCDONALD, M. R., AND GAY, H. I948. The enzymatic degradation of ribonucleoproteins of chromosomes, nucleoli and cytoplasm. Nature, Lond., I62, 814-815.

LA Cour, L. F. 1954. John Innes Annual Report, 1953.

MATHER, K. 1940. The determination of position in crossing-over. III. The evidence of metaphase chiasmata. 7. Genet., 39, 206-223.

plough, H. H. 1917. The effect of temperature on crossing-over in Drosophila. J. $\exp$. Zool., 24, 147-209.

PLOUGH, H. H. I $92 \mathrm{I}$. Further studies on the effect of temperature on crossing-over. J. $\exp$. Zool., 32, 187-202.

smith, н. F. 1936. The influence of temperature on crossing-over in Drosophila. Nature, Lond., ${ }_{138} 8,329-330$.

swanson, c. P. 1942a. Meiotic coiling in Tradescantia. Bot. Gaz., 103, 457-474.

SWANSON, c. P. $194^{2} b$. Some considerations of the phenomenon of chiasma terminalisation. Amer. Nat., 76, 593-6 ro.

sWANSON, C. P. 1943. The behaviour of meiotic prophase chromosomes as revealed through the use of high temperatures. Amer. J. Bot., 3o, 422-428.

White, M. J. D. I934. The influence of temperature on chiasma frequency. $J$. Genet., 29, 203-2 I5. 